\title{
Fisherman Attitude on Fisherman Insurance in Bandar Lampung City
}

\author{
I G Febryano ${ }^{1, *}$ M Rona ${ }^{1}$ A A Damai ${ }^{1}$ Hartoyo $^{1}$ E Rohana ${ }^{1}$ Novriyanti $^{1}$ \\ ${ }^{1}$ Graduate School of Coastal and Marine Zone Management, Universitas Lampung, Jl. S. Brodjonegoro No. 1, \\ Bandar Lampung, Indonesia \\ *Corresponding author. Email:indragumay@yahoo.com
}

\begin{abstract}
A fisherman insurance program is one of the government's policies to protect fisherman in their work. This study aims to explain the attitude of fisherman to fisherman insurance programs. The sampling technique used is non-probability sampling using the method of judgment sampling approach, which is based on certain criteria that have been determined in advance by the researcher. The result of this research shows that the attitude of fisherman to Fisherman Insurance is between neutral and maximum attitude values. The level of attribute importance that is considered very important for fisherman is that premium subsidies are inversely proportional to the level of performance that is not good at this attribute. It needs an extension to increase the awareness of fisherman self-protection by related parties and review of the policies of fisherman insurance programs.
\end{abstract}

Keywords: fisherman insurance, fisherman, risk, response attitude

\section{INTRODUCTION}

The fisherman is a profession that is very dependent on natural conditions. The factors that most influence the safety of fisherman are the weather and waves of the sea $[1,2]$. The maritime security situation often still haunts security and safety for fisherman [3]. Risk of bad weather or other events that can result in loss of income or loss of life from fisherman [4,5].

The existence of regulations is expected to be able to prosper the community, especially on the coast [6-9]. If any provision insurance, all risks of loss or loss of income expected can be transferred to the insurance company so that the hope is that fisherman and families are protected in supporting future life [10,11]. According to [9] the condition of traditional fishing boats that have not met the eligibility standards to prevent ship-to-sea accidents. This will certainly be a question of whether fisherman will participate in the insurance activities.

From 2016 up to 2018 the Fisherman Insurance Premium Assistance (Bantuan Premi Asuransi Nelayan/BPAN) target set by the Ministry of Marine Affairs and Fisheries Republic of Indonesia (Kementerian Kelautan dan Perikanan/KKP) is 500,000 fishermen each year. According to the Marine Affairs andFisheries Agency of Lampung Province (Dinas Kelautan dan Perikanan/DKP Provinsi Lampung), the BPAN target set by the KKP in 2018 for Lampung Province is 10,000 fishermen. However, only 1,873 fishermen can be realized.

According to Fishing Business Development of Marine Affairs and Fisheries Agency of Lampung

Province (Pengembangan Usaha Penangkapan Ikan/PUPI DKP Provinsi Lampung) in 2016, there were 2,510 fishermen registered with insurance in Bandar Lampung City. The government, through the KKP, continued this program for the fisherman who had never received BPAN in the previous year. So, in 2017, 54 fishermen participated in fisherman insurance. In 2018 246 fishermen participated in fisherman insurance, of which 213 were with BPAN and 33 were privately or attended. In this case, it can show the minimum level of participation in fisherman insurance and the fluctuation or change in the number of fisherman insurance registrants in Bandar Lampung City. The low level of participation or participation of fisherman towards insurance, so the authors consider it necessary to examine how the attitude of fisherman to fisherman insurance. 


\section{METHODS}

The sampling technique used is non-probability sampling where the collection of information and knowledge from respondents uses the judgment sampling approach, which is based on certain criteria that have been determined in advance by the researcher. Determination of the number of fisherman sampling in Bandar Lampung City, Lampung Province, Indonesia, using the Slovin Formula according to [12]:

$$
n=\frac{N}{1+N_{e}^{2}}=\frac{2,510}{(1+2,510) 0,1}=96,1=96 \text { people }
$$

where:

$$
\begin{aligned}
& \mathrm{n}=\text { sample size } \\
& \mathrm{N}=\text { population size } \\
& \mathrm{e}=\text { margin of error }
\end{aligned}
$$

Respondents are fishermen who have participated in the fisherman insurance (BPAN) premium assistance program in Bandar Lampung City, which is spread into four subdistricts, namely Bumi Waras (4 persons), Teluk Betung Timur (32 persons), Panjang (22 persons), and Teluk Betung Selatan (3 persons).

This study uses descriptive analysis and Fishbein Attitude Models, to show consumer responses to the characteristics of a product, the measurement size used is the Likert Scale. The choice of the Likert scale aims to determine the value of the indicators on the questionnaire. In its consideration, the Likert scale is relatively easy in denying higher score data indicating a higher attitude level of intensity compared to lower scores. The Fishbein model formulation [13] is as follows:

$$
A_{0}=\sum_{i=1}^{n} b_{i} e_{i}
$$

where:

$$
\begin{aligned}
& \mathrm{A}_{0}=\text { the attitudes of fisherman towards fisherman } \\
& \text { insurance. } \\
& \mathrm{b}_{\mathrm{i}}=\text { the strength of the fisherman's trust in the } i \\
& \text { attribute of the fisherman insurance } \\
& \mathrm{e}_{\mathrm{i}}=\text { fisherman evaluation of attributes in } i \text { general } \\
& \mathrm{n}=\text { number of attributes }
\end{aligned}
$$

The range of scale to be used is adjusted according to the formula:

where

$$
R S=\frac{b-n}{m-n}
$$

\footnotetext{
$\mathrm{RS}=$ range scale

$\mathrm{m}=$ highest scores

$\mathrm{n}=$ lowest score

$\mathrm{b}=$ number of classes (in this study five class categories will be used)
}

Based on a large number of respondents (96 respondents), the smallest average value that may be obtained is 1 and the largest average value that may be obtained is 5 , then the magnitude of the range for the evaluation of importance and level of trust is 0,8 . So the range of scales at the level of importance and level of trust are as follows:

- $1,00<\mathrm{x} \leq 1,80$ means it's not very important

- $1,80<\mathrm{x} \leq 2,60$ means it's not important

- 2,60<x $\leq 3,40$ means quite important

- 3,40<x $\leq 3,20$ means important

- $4,20<\mathrm{x} \leq 5,00$ means very important

\section{RESULTS AND DISCUSSION}

\subsection{Characteristic of Respondent}

Table 1 shows that the majority of the respondent with the most age distribution were $31-40$ years old $(33.00 \%)$. While at the education level of the highest respondents received high school education with a percentage of $20.00 \%$ and for the education level most widely taken by the respondent were junior high schools were as many as $32.25 \%$ fishermen. As many as $50.00 \%$ of fishermen get the number of catches ranged from $11-30 \mathrm{~kg}$. The total number of non-ship vessels used privately owned by $63.50 \%$ of respondents. According to [14] in the case of agriculture, young and highly educated farmers are more supportive of the agricultural insurance program. In line with research [15] which states that education level is a significant factor influencing farmers to take part in agricultural insurance.

\subsection{Fisherman's attitudes in the fisherman insurance program}

In assessing the overall satisfaction of fisherman and knowing the attributes that need attention. It is necessary to assess the importance and performance of the attributes. From the level of importance and performance will be known to what extent the level of performance attributes can meet the needs of fisherman. The fisherman insurance attributes that will be discussed are grouped based on the 7P marketing mix, namely product, price, place, promotion, process, physical environment, and stakeholders. To find out the attitudes of fisherman to the attributes of the fisherman's insurance, it was tested using the Fishbein attribute model. 
Table 1. Characteristics of the respondent

\begin{tabular}{|c|c|c|c|}
\hline Characteristics & Category & $\begin{array}{l}\text { Amount } \\
\text { (persons) }\end{array}$ & $\%$ \\
\hline \multirow[t]{6}{*}{ Age (year) } & $17-30$ & 9 & 9.40 \\
\hline & $31-40$ & 32 & 33.00 \\
\hline & $41-50$ & 24 & 25.00 \\
\hline & $51-60$ & 18 & 19.00 \\
\hline & $>60$ & 13 & 13.60 \\
\hline & Total & 96 & 100.00 \\
\hline \multirow[t]{6}{*}{ Level of education } & No School & 22 & 23.00 \\
\hline & Elementary school & 25 & 26.00 \\
\hline & Middle School & 30 & 32.25 \\
\hline & High school & 19 & 20.00 \\
\hline & College & 0 & 0.00 \\
\hline & Total & 96 & 100.00 \\
\hline \multirow[t]{5}{*}{ Daily catch amount (kg) } & $<5$ & 10 & 10.40 \\
\hline & $5-10$ & 23 & 24.00 \\
\hline & $11-30$ & 48 & 50.00 \\
\hline & $>30$ & 15 & 15.60 \\
\hline & Total & 96 & 100.00 \\
\hline \multirow[t]{3}{*}{ Ship ownership status } & one's own & 61 & 63.50 \\
\hline & the crew & 35 & 36.50 \\
\hline & Total & 96 & 100.00 \\
\hline
\end{tabular}

This model includes two important things, namely the attribute that is desired or evaluated by consumers is called an evaluation score (ei) and the level of performance that is evaluated is called a trust score (bi). In this analysis, respondents provide an assessment according to a predetermined scale of product attributes then attitudes will be obtained (Ao or bi*ei) and the total value. The level of importance of attributes can be seen in Table 2.

The greatest importance of the product mix is the registration requirement of 4.58 This is because every fisherman who wants to follow a fisherman's insurance program is required to have a fisherman card or KUSUKA card. If a fisherman does not have the card, fisherman can not register either through premium assistance or independently. As for the guaranteed risk and the claim coverage value, it is also important with the value of 4.46 and 4.55 . Risks borne by fisherman insurance are medical expenses in the event of accidents both on land and at sea, permanent disability, and death.

In terms of distribution or ease of obtaining information, the value is 4.69 followed by the value of

registration ease of 4.66 and the ease of accessing the location of PT Jasindo 4.50. In searching for information about Fisherman Insurance, fisherman can directly ask the importance of the mix of attributes of the most important process attributes, namely the head of the group, fisheries or PT Jasindo instructors either directly at the meeting or via telephone. Time of claim disbursement with a value of 4.60 and which has the lowest interest is on the fulfilment of the claim completeness documents with a value of 4.07.

The physical environment is the facilities and services owned by service companies in offering their products. Physical evidence on insurance companies such as public facilities such as offices and bid proposals are quite easy to understand. The highest importance of the physical environment to the fisherman's insurance is a letter registration form, a health statement and a bank account with a value of 4.48. Also, according to the fisherman, the most important price mix is the premium subsidy with a value of 4.84 , with the expectation that the subsidy can make fisherman even more interested. 
Table 2. Importance Mix Attributes

\begin{tabular}{|c|c|c|c|c|c|c|c|c|}
\hline \multirow{2}{*}{ Mix } & \multirow{2}{*}{ Attributes } & \multicolumn{4}{|c|}{ Importance } & \multirow[b]{2}{*}{5} & \multirow{2}{*}{ Total } & \multirow{2}{*}{ ei } \\
\hline & & 1 & 2 & 3 & 4 & & & \\
\hline \multirow[t]{4}{*}{ Product } & Registration requirements & 0 & 0 & 5 & 30 & 61 & 440 & 4.58 \\
\hline & Guaranteed risks (work & 0 & 0 & 10 & 32 & 54 & 428 & 4.46 \\
\hline & $\begin{array}{l}\text { accident, permanent disability, } \\
\text { death) }\end{array}$ & & & & & & & \\
\hline & Claim coverage value & 0 & 0 & 3 & 37 & 56 & 437 & 4.55 \\
\hline \multirow[t]{3}{*}{ Place (Distribution) } & Ease of Registration & 0 & 0 & 2 & 29 & 65 & 447 & 4.66 \\
\hline & Ease of making a claim & 0 & 1 & 1 & 43 & 51 & 432 & 4.50 \\
\hline & Ease of getting information & 0 & 0 & 0 & 30 & 66 & 450 & 4.69 \\
\hline \multirow[t]{3}{*}{ Process } & How to register & 0 & 0 & 11 & 22 & 63 & 436 & 4.54 \\
\hline & How to submit a claim & 0 & 0 & 13 & 33 & 50 & 421 & 4.39 \\
\hline & Duration of claim paid & 0 & 0 & 5 & 42 & 49 & 428 & 4.46 \\
\hline \multirow{3}{*}{$\begin{array}{l}\text { Physical } \\
\text { environment }\end{array}$} & Letter registration form, health & 0 & 0 & 10 & 30 & 56 & 430 & 4.48 \\
\hline & statement and bank account & & & & & & & \\
\hline & $\begin{array}{l}\text { Claim forms and minutes of } \\
\text { events }\end{array}$ & 0 & 0 & 23 & 23 & 50 & 411 & 4.19 \\
\hline \multirow[t]{2}{*}{ Price } & Premium price & 0 & 0 & 0 & 26 & 70 & 454 & 4.73 \\
\hline & Premium subsidies & 0 & 0 & 0 & 15 & 81 & 465 & 4.84 \\
\hline \multirow[t]{4}{*}{ Promotion } & Socialization & 0 & 0 & 7 & 25 & 64 & 441 & 4.59 \\
\hline & Leaflet & 0 & 1 & 12 & 32 & 51 & 421 & 4.39 \\
\hline & Banner & 0 & 1 & 21 & 31 & 43 & 404 & 4.21 \\
\hline & Internet & 0 & 0 & 10 & 41 & 45 & 419 & 4.36 \\
\hline \multirow[t]{4}{*}{ Stakeholders } & Group leader & 0 & 0 & 0 & 26 & 70 & 454 & 4.73 \\
\hline & Fisheries instructor & 0 & 0 & 0 & 12 & 84 & 468 & 4.88 \\
\hline & Jasindo employees & 0 & 0 & 2 & 15 & 79 & 461 & 4.80 \\
\hline & DKP Provinsi Lampung officer & 0 & 0 & 14 & 24 & 58 & 428 & 4.46 \\
\hline
\end{tabular}

Educative communication is a way of marketing service products that are used specifically for new customers. Providing information must be done by the service provider to the customer regarding the benefits of the services offered, where and when to get it and how to participate in the service process to get the best results. Promotional activities of service companies can be done with various media and direct communication with prospective service users to create effective communication. The highest level of importance in the promotion mix lies in the socialization of 4.59. This means that the socialization felt by a fisherman is very important to increase this knowledge because the fisherman as customers can communicate directly if there are things that are not yet understood about the products offered. Communication is inseparable from the stakeholders involved in it. The stakeholder's fisherman insurance that can influence is the group leader, fisheries instructor, Jasindo employees, and DKP Provinsi Lampung officer. fisheries instructors get the highest importance value, which is 4.88 .
The performance level of the best attributes according to the fisherman (Table 3 ) is on the claim disbursed because it is following the time set by the technical guideline which is 14 working days after the file is declared complete by PT Jasindo. When viewed per mix the attributes on the product mix have been said to be quite good with the lowest value of 2.80 which is the risk that can be claimed while the attribute requirements for registration and the coverage value in the range of values is either 3.30 and 3.50. In the mix of places that get very poor value, namely the period of claim reporting. The fisherman still does not know the length of time determined if there is an accident, thus making the fisherman cannot be claimed because the reporting period has expired. On the physical environment attribute, the performance is still said to be poor, namely the value of the letter and health statement from the registration form and the account value of 2.40 and the attribute of the claim form and minutes at 1.90. One of the main factors is the poor performance of attributes because fisherman has difficulty in making savings accounts in the bank. 
The premium price attribute can be said to be good at 3.50 but different from the performance of the premium subsidy of 2.70 where the fisherman is only given a full one-time subsidy and then the fisherman must pay for himself. In terms of premium prices, fisherman says they can pay from the premium amount of Rp 175,000, - but fisherman has hopes of returning subsidies, although not given in full. Promotion mix performance is considered not good either in socialization, banner leaflets and internet on the socialization attribute with the most influential stakeholders, namely the group leader and followed by fisheries instructor. For promotion using the attribute of banners and leaflets or brochures in the poor assessment because it has not touched the entire coastal area of Bandar Lampung City.

Table 3. Level of Performance Mix Attributes

\begin{tabular}{|c|c|c|c|c|c|c|c|c|}
\hline \multirow{2}{*}{ Mix } & \multirow{2}{*}{ Attributes } & \multicolumn{5}{|c|}{ Importance } & \multirow{2}{*}{ Total } & \multirow{2}{*}{ bi } \\
\hline & & 1 & 2 & 3 & 4 & 5 & & \\
\hline \multirow[t]{5}{*}{ Product } & Registration requirements & 12 & 18 & 20 & 24 & 22 & 314 & 3.30 \\
\hline & Guaranteed risks (work & 16 & 29 & 21 & 18 & 12 & 269 & 2.80 \\
\hline & accident, permanent & & & & & & & \\
\hline & disability, death) & & & & & & & \\
\hline & Claim coverage value & 0 & 28 & 23 & 10 & 35 & 340 & 3.50 \\
\hline \multirow[t]{3}{*}{ Place (Distribution) } & Ease of Registration & 15 & 38 & 31 & 2 & 10 & 242 & 2.50 \\
\hline & Ease of making a claim & 43 & 15 & 29 & 0 & 9 & 205 & 2.10 \\
\hline & Ease of getting information & 0 & 22 & 7 & 4 & 63 & 396 & 4.10 \\
\hline \multirow[t]{3}{*}{ Process } & How to register & 45 & 21 & 23 & 7 & 0 & 184 & 1.90 \\
\hline & How to submit a claim & 22 & 43 & 18 & 9 & 4 & 218 & 2.30 \\
\hline & Duration of claim paid & 34 & 20 & 28 & 14 & 0 & 214 & 2.20 \\
\hline \multirow[t]{2}{*}{ Physical environment } & $\begin{array}{l}\text { Letter registration form, } \\
\text { health statement and bank } \\
\text { account }\end{array}$ & 0 & 61 & 32 & 3 & 0 & 230 & 2.40 \\
\hline & $\begin{array}{l}\text { Claim forms and minutes of } \\
\text { events }\end{array}$ & 33 & 41 & 20 & 2 & 0 & 183 & 1.90 \\
\hline \multirow[t]{2}{*}{ Price } & Premium price & 13 & 5 & 10 & 55 & 13 & 338 & 3.50 \\
\hline & Premium subsidies & 30 & 24 & 14 & 3 & 25 & 257 & 2.70 \\
\hline \multirow[t]{4}{*}{ Promotion } & Socialization & 77 & 15 & 4 & 0 & 0 & 119 & 1.20 \\
\hline & Leaflet & 44 & 32 & 5 & 5 & 10 & 193 & 2.00 \\
\hline & Banner & 40 & 33 & 23 & 0 & 0 & 175 & 1.80 \\
\hline & Internet & 41 & 53 & 2 & 0 & 0 & 153 & 1.60 \\
\hline \multirow[t]{4}{*}{ Stakeholders } & Group leader & 0 & 35 & 51 & 2 & 8 & 271 & 2.80 \\
\hline & Fisheries instructor & 0 & 42 & 50 & 4 & 0 & 250 & 2.60 \\
\hline & Jasindo employees & 71 & 21 & 4 & 0 & 0 & 125 & 1.30 \\
\hline & $\begin{array}{l}\text { DKP Provinsi Lampung } \\
\text { officer }\end{array}$ & 59 & 31 & 6 & 0 & 0 & 139 & 1.40 \\
\hline
\end{tabular}

While socialization is highly dependent on the activeness of group leaders and fisheries instructor in Bandar Lampung City. This causes unevenness of fisherman who has followed the fisherman's insurance both who have just followed and who want to extend fisherman insurance again. In determining the response of fisherman's attitudes, it can be seen from the large value of interests and the value of performance that has been done in the fisherman's insurance program. The results of the calculation of Multiattribute Fishbein attitude models can be seen in Table 4. 
Table 4. The calculation results of the Fishbein Multiatribut Attitude Model.

\begin{tabular}{|c|c|c|c|c|}
\hline 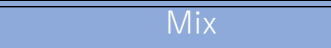 & Attributes & $\overline{e i}$ & $\overline{b i}$ & AO \\
\hline \multirow[t]{3}{*}{ Product } & Registration requirements & 4.58 & 3.30 & 15.10 \\
\hline & $\begin{array}{l}\text { Guaranteed risks (work accident, permanent } \\
\text { disability, death) }\end{array}$ & 4.46 & 2.80 & 12.50 \\
\hline & Claim coverage value & 4.55 & 3.50 & 15.90 \\
\hline \multirow[t]{3}{*}{ Place (Distribution) } & Ease of Registration & 4.66 & 2.50 & 11.70 \\
\hline & Ease of making a claim & 4.50 & 2.10 & 9.50 \\
\hline & Ease of getting information & 4.69 & 4.10 & 19.20 \\
\hline \multirow[t]{3}{*}{ Process } & How to register & 4.54 & 1.90 & 8.60 \\
\hline & How to submit a claim & 4.39 & 2.30 & 10.10 \\
\hline & Duration of the claim paid & 4.46 & 2.20 & 9.80 \\
\hline \multirow[t]{2}{*}{ Physical environment } & $\begin{array}{l}\text { Letter registration form, health statement and } \\
\text { bank account }\end{array}$ & 4.48 & 2.40 & 10.80 \\
\hline & Claim forms and minutes of events & 4.19 & 1.90 & 8.00 \\
\hline \multirow[t]{2}{*}{ Price } & Premium price & 4.73 & 3.50 & 16.60 \\
\hline & Premium subsidies & 4.84 & 2.70 & 13.10 \\
\hline \multirow[t]{4}{*}{ Promotion } & Socialization & 4.59 & 1.20 & 5.50 \\
\hline & Leaflet & 4.39 & 2.00 & 8.80 \\
\hline & Banner & 4.21 & 1.80 & 7.60 \\
\hline & Internet & 4.36 & 1.60 & 7.00 \\
\hline \multirow[t]{5}{*}{ Stakeholders } & Group leader & 4.73 & 2.80 & 13.20 \\
\hline & Fisheries instructor & 4.88 & 2.60 & 12.70 \\
\hline & Jasindo employees & 4.80 & 1.30 & 6.20 \\
\hline & DKP Provinsi Lampung officer & 4.46 & 1.40 & 6.20 \\
\hline & & & Total & 228.00 \\
\hline
\end{tabular}

In the above data, it can be seen that the attitude of the fisherman on the attribute mix is on a neutral attitude with a value of 228.00 with the highest value on the ease of accessing the location of PT Jasindo that is equal to 19.20 and the smallest attitude value is on socialization which is at a value of 5.50 shows that socialization activities carried out are still lacking, making the low number of fisherman who follows the fisherman's insurance. A study conducted by [16] to showed that the poor performance of fisheries insurance in India can be improved through bridging the trust deficit amongst the stakeholders, bringing about attitudinal changes through awareness drives, developing innovative institutional mechanisms, and leveraging the potential of technological interventions.

\section{CONCLUSIONS}

The attitudes of fisherman to the attributes of Fisherman Insurance are all positive values with different attitude ratings. The highest attitude of consumers lies in the ease of claim realization attributes. This shows that the realization of claims has gone well. The lowest attitude score lies in the socialization. Fisherman feels the need for evenly promoted promotion and outreach activities because there are still many fishermen who do not know the fisherman's insurance program. Fisherman can increase the awareness of their self-protection through extension by related parties. Besides that, it is needed to review the policies of fisherman insurance programs so the fisherman can be following the things that are considered.

\section{REFERENCES}

[1] L. Adam, Study On Protection Of Fishermen And Fish Farmers In Indonesia, Kajian, 2015, pp. 145-162.

[2] A. Satria, Pengkajian Hukum Tentang Perlindungan Nelayan Tradisional Dalam Pengelolaan Sumber Daya Kelautan, BadanPembinaan Hukum Nasional, Jakarta, 2012.

[3] A. Helmi, A. Satria, Fisher's Adaptation Strategies to Ecological Changes Abstract, Makara Hubs-Asia 16, 2012, pp. 68-78.

[4] M. Rani, Insurance Protection For Fisherman, Selat, 2016, pp. 1-14.

[5] T. Akbar, M. Huda, Nelayan, Lingkungan, dan Perubahan Iklim (Studi Terhadap Kondisi Sosial Ekonomi Pesisir di Kabupaten Malang), 
WAHANA, 2017, pp. 49-52.

[6] M.L. Salampessy, I.G. Febryano, D. Zulfiani, Bound by debt: Nutmeg trees and changing relations between farmers and agents in a Moluccan agroforestry systems, Forest and Society 1, 2017, pp. 137-143.

[7] I.G. Febryano, D. Suharjito, D. Darusman, C. Kusmana, A. Hidayat, The roles and sustainability of local institutions of mangrove management in Pahawang Island, Jurnal Manajemen Hutan Tropika, 2014, pp. 69-76.

[8] Y. Yuliasamaya, A. Darmawan, R. Hilmanto, Mangrove Forest Cover Change Along the Coast of East Lampung Regency, Jurnal Sylva Lestari, 2014, pp. 111.

[9] D. Alfandi, R. Qurniati and I.G. Febryano, Community Participation in Mangrove Management, Jurnal Sylva Lestari, 2019, pp. 30.

[10] A. Salim, Asuransi Dan Manajemen Risiko, PT Raja Grafindo Persada, Jakarta, 2007.

[11] A. Diamantina, Penegakan Hukum Pidana di Perikanan, Universitas Diponegoro, 2001.

[12] S. Sugiyono, Metode Penelitian Kuantitatif
Kualitatif Dan R \& D, Alfabeta, Bandung, 2007.

[13] J. Engel, R. Blackwell, P. Miniard, Consumer Behavior, The Dryden Press, Orlando, 1995.

[14] G. Enjolras, F. Capitanio, F. Adinolfi, The demand for crop insurance: Combined approaches for France and Italy, Agricultural Economics Review, 2012, pp. 5-22.

[15] H.H. Wang, S.D. Hanson, J.R. Black, Efficiency costs of subsidy rules for crop insurance, Journal of Agricultural and Resource Economics, 2003, pp. 116-137.

[16] S. Parappurathu, C. Ramachandran, A. Gopalakrishnan, D. Kumar, M.K. Poddar, M. Choudhury et al., What ails fisheries insurance in India? An assessment of issues, challenges and future potential, Marine Policy, 2017, pp. 144- 155 . 